\title{
Effectiveness of Beet Juice, Potato and Ambon Banana Diet to The Elderly with Hypertension for Blood Pressure
}

\author{
Sri Lestari Dwi Astuti ${ }^{*}$, Yeni Tutu Rohimah ${ }^{2}$ \\ Poltekkes Kemenkes Surakarta Jurusan Keperawatan \\ *Email: srilestarida18@gmail.com
}

\begin{abstract}
Background: Hypertension is often called as "silent killer" and the common cause of cardiovascular disease. It's also the main problem in both developed and developing country. The management of hypertension must be integrated between the essential standard medication and altering the life style which involved dietary habit management, stress coping management, activity management, avoiding alcohol and smoking. Purpose this study to analyze the effectiveness of beet juice, potato and ambon banana for blood pressure of the elderly with hypertension. Methods: The research design was pre experiment with Pre and Post Control Group Design. The independent variable was the beet juice, potato and ambon banana. The dependent variable was the blood pressure. The sample was the elderly with hypertension who take hypertension medication periodically. The sample consisted of 66 respondents. The blood pressure was examined once aten days for a month. The data analysis was chi-square. Results: There was reduction of the blood pressure for $99.7 \%$ respondents. Conclusion: Beet juice, potato and ambon banana are effective in lowering the blood pressure of elderly with hypertension.
\end{abstract}

Keywords: hipertension, life of healthy

\section{PENDAHULUAN}

Hipertensi sering disebut sebagai "silent killer"dan merupakan penyebab paling umum terjadinya penyakit kardiovaskular dan merupakan masalah utama di Negara maju maupun berkembang. Data riskesdas tahun 2018 prevalensi darah tinggi pada usia> 15 tahun adalah 34,1\%. Daerah yang paling tinggi prevalensi hipertensi adalah Sulawesi Utara yaitu 13, $2 \%$ dan yang paling rendah adalah Padang 4,4 \%, sedangkan Jateng adalah $8,4 \%$. Prevelensi hipertensi menurut karakteristik jenis kelamin laki-laki $31,3 \%$ perempuan $36,9 \%$, sedang menurut daerah prevalensi di perkotaan $34,4 \%$ dan pedesaan 33, $7 \%$ (Kemenkes RI, 2019).

Hipertensi sangat erat hubungannya dengan berbagai ragam faktor risiko, baik yang tidak dapat diubah maupun yang dapat diubah. Faktor risiko yang tidak dapat diubah diantaranya genetik, keadaan gizi, dan umur, sedangkan faktor risiko yang dapat diubah adalah kegemukan, Kolesterol yang tinggidalamdarah, stress, rokok, kafein, alkohol, kurangnya aktifitas fisik/olahraga serta diet yang salah. Makanan merupakan salah satu faktor lingkungan yang dapatmemicu terjadinya hipertensi. Hal ini dikarenakan gaya hidup yang serba praktis memanjakan masyarakatuntuk mengkonsumsi makanan siap saji yang didalamnya lebih banyak mengandung lemak jenuh, kadar garam, kadar gula yang terlalu tinggi, dan zat kimia tambahan. Makanan jenis ini hampir tidak memiliki kandungan protein, vitamin, ataupun serat dalam jumlah yang dibutuhkan tubuh sehingga memicu peningkatan kolesterol dalam darah (Ditjen Yankes, 2018). Dari hasil penelitian Dietary Approaches to Stop Hypertension (DASH) tentang diet dengan mengkonsumsi tinggi sayur, buah, dan hasil olahan susu rendah 
lemak yang kadar lemak jenuh dan lemak totalnya rendah serta tinggi kandungan kalium, kalsium, dan magnesium dapat menurunkan tekanan darah sistolik 6-11 mmHg dan tekanan darah diastolik 3-6 mmHg (Hima J, et al, 2018).

Penatalaksanaan hipertensi harus diintegrasikan antara pilar pengobatan standard dan merubah gaya hidup yang meliputi mengatur pola makan, mengatur koping stress, mengatur pola aktivitas, menghindari alkohol, dan rokok (Dalimartha, 2008).

\section{METODE PENELITIAN}

Jenis penelitian adalah Preexperimental dengan rancangan One Group Pretest-Posttest Design (Sugiyono, 2010). Variabel bebas Jus bit, Kentang dan pisang ambon, variable terikat tekanan darah. Sampel penelitian lansia di Posyandu Lansia Kelurahan Sudiroprajan dengan usia
50-86 tahun yang mengalami hipertensi yang rutin minum obat hipertensi, cara pengambilan sampel purposive sampling berjumlah 66 responden. Cara penelitian responden dilakukan pemeriksaan kadar kolesterol dan kadar gula darah untuk memastikan tidak ada komplikasi, selanjutnya diberikan informed concent, penyamaan persepsi cara perlakuan kepada enumerator, pemberian Jus bitdari 100 gram bit menjadi 100 cc jus bit kepada responden pada jam 07.00, jam 10.0011.00 responden diberi pisang ambon seberat 140 gram dengan kulit yang dimakan tanpa kulit, jam 15.00 responden diberi kentang kuning seberat 100 gram berlangsung selama 1 bulan. Pemeriksaan tekanan darah dilakukan setiap 10 hari selama 1 bulan, pemeriksaan kadar gula darah dan kolesterol dilakukan sebelum dan setelah pemberian diet.

\section{HASIL DAN PEMBAHASAN}

Tabel 1. Tekanan Darah Sebelum dan Setelah Perlakuan $(n=66)$

\begin{tabular}{lcccc}
\hline \multicolumn{1}{c}{ Derajat Hipertensi } & $\begin{array}{c}\text { Sebelum } \\
\text { Perlakuan }\end{array}$ & Persen (\%) & $\begin{array}{c}\text { Setelah } \\
\text { Perlakuan }\end{array}$ & $\begin{array}{c}\text { Persen } \\
(\%)\end{array}$ \\
\hline $\begin{array}{l}\text { Normal } \\
(120 / 80 \text { mmHg) }\end{array}$ & 0 & 0 & 34 & 54 \\
$\begin{array}{l}\text { Pra Hipertensi } \\
(130-139 / 80-89 \text { mmHg) }\end{array}$ & 0 & 0 & 27 & 38 \\
$\begin{array}{l}\text { Hipertensi Derajat 1 } \\
(140-159 / 90-99 \text { mmHg) }\end{array}$ & 51 & 77,3 & 4 & 6 \\
$\begin{array}{l}\text { Hipertensi derajat } 2 \\
(160-179 / 100-109\end{array}$ & 15 & 22,7 & 1 & 1 \\
$\begin{array}{l}\text { mmHg) } \\
\text { Hipertensi Derajat } 3 \\
(>180 />110 m m H g)\end{array}$ & & & & \\
\hline
\end{tabular}

\section{Keterangan}

Tekanan darah sebelum diberikan jus bit, kentang dan pisang sebagian besar lansia 51 orang $(77,3 \%)$ mengalami hipertensi derajat 1 dan 15 orang lansia $(22,7 \%)$ mengalami hipertensi derajat 2. Setelah diberikan jus bit, kentang dan pisang selama 1 bulan terjadi perubahan yang sifnifikan. Dari 66 responden, 34 lansia (54\%) tekanan darah menjadi normal, 
27 lansia (38\%) menjadi pra hipertensi, hanya 4 lansia $(6 \%)$ yang mengalami hipertensi derajat 1 dan 1 lansia (1\%) yang mengalami hipertensi derajat 2 . Hasil analisis chi-square $\mathrm{p}=0.000, \mathrm{p}<$ 0,05 , Ada pengaruh yang signifikan diet jus bit, kentang dan pisang ambon terhadap penurunan tekanan darah lansia hipertensi.

Baik jus bit, kentang dan pisang ambon memiliki kandungan kalium, kalsium dan magnesium. Kalium yang tinggi di dalam tubuh secara langsung mempengaruhi tekanan darah. Dengan kehadiran $\mathrm{K}^{+}$di dalam ekstra sel menyebabkan cairan ekstrasel lebih positif yang akan mengaktifkan pompa Natrium - Kalium dan membuka saluran Kalium- Natrium, Natrium di dalam intra sel akan berpindah ke dalam cairan ekstrasel bersama clorida, sedangkan kalium akan berpindah kedalam cairan intra sel, Natrium Clorida akan menarik cairan ke ekstrasel sehingga cairan ekstrasel menjadi lebih banyak yang akhirnya akan diekresikan kedalam ginjal sebagai urine, pengeluaran cairan yang banyak lewat urine dapat berdampak pada penurunan tekanan darah. (Guyton, A. C., Hall, J. E., 2014).

Kadar kalsium di dalam darah penting karena kalsium juga memiliki peranan penting dalam pengaturan tekanan darah dengan cara membantu kontraksi otot-otot pada dinding pembuluh darah serta membersinya untuk pelepasan hormon-hormon yang berperan dalam pengaturan tekanan darah. Kerja duet dari magnesium dan kalsium inilah yang berguna untuk mempertahankan irama jantung tetap normal dengan relaksasi dan kontraksi otot jantung . Gabungan asupan Magnesium dan Kalsium dapat berpengaruh terhadap tekanan darah (Krummel, D.A., 2008).

Magnesium mempunyai peranan penting dalam upaya pengontrolan tekanan darah dengan memperkuat jaringan endotel, menstimulasi prostaglandin dan meningkatkan penangkapan glukosa sehingga resistensi insulin dapat terkurangi. Selain itu, magnesium juga berperan dalam kontraksi otot jantung. Bila konsentrasi magnesium dalam darah menurun maka otot jantung tidak dapat bekerjasecara maksimal sehingga mempengaruhi tekanan darah (Kotchen TA, 2006).

Buah bit mengandung Phytonitrat yang diubah menjadi nitrit ketika diserap oleh tubuh.Nitrit berkhasiat membuat jaringan otot menjadi rileks dan menurunkan aliran darah sehingga tekanan darah pun menurun. Buah bit secara alami dapat membantu kesehatan fungsi pembuluh darah dan melawan homo sistein, yang dapat merusak pembuluh darah (Diego A. Bonilla Ocampo, 2018).

\section{KESIMPULAN DAN SARAN}

Pemberian jus bit, kentang dan pisang ambon dapat menurunkan tekanan darah lansia hipertensi. Oleh sebab itu pada lansia yang menderita hipertensi sebaiknya tetap minum obat secara rutin dan memodifikasi makanan sehari-hari dengan jus bit, kentang, dan pisang ambon agar tekanan darah dalam kondisi stabil

\section{DAFTAR RUJUKAN}

Andrea, G., Chasani, S., \& Ismail, A. (2013). Korelasi Derajat Hipertensi Dengan Stadium Penyakit Ginjal Kronik Di RSUP Dr. Kariadi Semarang Periode 2008-2012. 
JurnalKedokteranDiponegoro, 2(1), 8-28.

Bonilla Ocampo, D. A., Paipilla, A. F., Marín, E., Vargas-Molina, S., Petro, J. L., \& Pérez-Idárraga, A. (2018). Dietary Nitrate from Beetroot Juice for Hypertension: A Systematic Review. Biomolecules, 8(4), 112.https://doi.org/10.3390/biom80 40134

Budijanto, D. (2013). Populasi, Sampling, dan Besar Sampel. KementerianKesehatan RI. Retrieved from http://www.risbinkes.litbang.depk es.go.id/2015/wpcontent/uploads/2013/02/Samplin g-Dan-Besar-Sampel.pdf

Dosh, S. A. (2001). The diagnosis of essential and secondary hypertension in adults. Journal of Family Practice, 50(8), 707-712

Farrar, G. R., \& Zhang, H. (1990). Erratum: Perturbative QCD calculation of real and virtual Compton scattering (Physical Review D (1990) 42, 7 (2413)). Physical Review D, 42(7), 2413.https://doi.org/10.1103/Phys $\underline{\text { RevD.42.2413 }}$

Indrawati, S., Yuliet, \& Ihwan. (2015). Efek Anti Diabetes Ekstrak Air Klit Buah Pisang Ambon (Musa paradisiaca L) Terhadap Mencit ( Musmusculus) Model Hiperglycemia. Journal of Pharmacy, 2(1), 133-140.

Kamura, A., Kajiya, K., Kishi, H., Inagaki, J., Mitarai, M.,
OdaH.,..Kobayashi, S. (2016). Effects of the DASH-JUMP dietary intervention in Japanese participants with high-normal blood pressure and stage1 hypertension: An open-label single arm trial. Hypertension Research, 89(11), 777-785. https://doi.org/10.1038/hr.2016.76

Kemenkes RI. (2018). Hasil Utama Riskesdas. Journal of Phisics A.: Mathematical and Theoretichal. 44(8),1-200. http://doi.org/10.10 $\underline{88 / 1751-8113 / 44 / 8 / 085201}$.

Kemenkes RI. (2014). Pusdatin Hipertensi, Infodatin,(Hipertensi), 1-2. $\quad$ http://doi.org/10.1177/ 109019817400200403

Krummel, D.A. (2008). Medical Nutrition Therapy for Cardiovascular Disease. In:Mahan, L.K., Escott-Stump, S., Krausse's Food and Nutirition Therapy. Canada: Saunders Elsvier, 834835.

Ningrat, R.,W., \&Santosa, B. (2012). Pemilihan Diet Nutrien Bagi Penderita Hipertensi Menggunakan Metode Klasifikasi Decision Tree (Studi Kasus : RSUD Syarifah Ambami Rato Ebu Bangkalan, Jurnal Teknik ITS, Vol 1(1), 536-539

No, J. S. (2015). Pengaruh Pemberian Psang Kepok (Musa paradisiaca forma typical) Terhadap Kadar Glucosa Darah Puasa Pada Tikus Sprage Dawley Pra Syndrom Metabolik.4(4), 547556.https://doi.org/10.14710jnc.v $\underline{4 \mathrm{i} 4.10161}$ 
Poli, R., Engka, J., \&Sapulete, I.,M. (2016). Hubungan nada atrium dengan tekanan darah pada remaja di Kecamatan Bonga lintang Barat Kabupaten Bolaang Mongondow Utara, Jurnal E-Biomedik, 4(2), 37-45.

https://doi.org/10.35790/ebm.4.2.2 $\underline{016.14862}$

Puspita, A., \&Aisyah, S. (2012). Sikap Terhadap Kepatuhan Diit Hipertensi Dengan Tekanan Darah Pada penderita Hipertensi Di Wilayah KerjaPuskesmas Doro II Kabpaten Pekalongan, Jurnal Keperawatan, 5

Sutria, E., \&Insani, A. (2013). Pengaruh Konsumsi Pisang Ambon Terhadap Penurunan Tekanan Darah Pra Lansia Hipertensi. Journal of Islamic Nursing, 1(1), 33-41. Retrieved from journal.uin-alaudin. ac.id/index.php/join/article/dowlo $\mathrm{ad} / . . . / 3282$

Yulianti, I. (2019). Pengaruh Pemberian Pisang Ambon Terhadap tekanan Darah Pada Lansia Penderita Hipertensi, Jurnal Ners dan Kebidanan (Journal of Ners and Midwifery), 6(1),070-076. http://doi.org/10.266/jnk.v6i.at.p0 70-076 